Research article

\title{
Hormone replacement therapy in rheumatoid arthritis is
} associated with lower serum levels of soluble IL-6 receptor and higher insulin-like growth factor 1

\author{
Helena Forsblad d'Elia ${ }^{1}$ Lars-Åke Mattsson², Claes Ohlsson ${ }^{3}$, Elisabeth Nordborg ${ }^{1}$ and \\ Hans Carlsten ${ }^{1}$
}

\author{
1Department of Rheumatology and Inflammation Research, The Sahlgrenska Academy at Göteborg University, Göteborg, Sweden \\ ${ }^{2}$ Department of Obstetrics and Gynecology, The Sahlgrenska Academy at Göteborg University, Göteborg, Sweden \\ ${ }^{3}$ Department of Internal Medicine, The Sahlgrenska Academy at Göteborg University, Göteborg, Sweden \\ Correspondence: Helena Forsblad d'Elia (e-mail: helena.forsblad@rheuma.gu.se)
}

Received: 18 Oct 2002 Revisions requested: 5 Dec 2002 Revisions received: 12 Mar 2003 Accepted: 21 Mar 2003 Published: 1 May 2003

Arthritis Res Ther 2003, 5:R202-R209 (DOI 10.1186/ar761)

(C) 2003 Forsblad d'Elia et al., licensee BioMed Central Ltd (Print ISSN 1478-6354; Online ISSN 1478-6362). This is an Open Access article: verbatim copying and redistribution of this article are permitted in all media for any purpose, provided this notice is preserved along with the article's original URL.

\begin{abstract}
Hormone replacement therapy (HRT) modulates the imbalance in bone remodeling, thereby decreasing bone loss. Sex hormones are known to influence rheumatic diseases. The aim of this study was to investigate the effects of HRT on the serum levels of hormones and cytokines regulating bone turnover in 88 postmenopausal women with active rheumatoid arthritis (RA) randomly allocated to receive HRT plus calcium and vitamin $D_{3}$ or calcium and vitamin $D_{3}$ alone for 2 years. An increase in estradiol $\left(E_{2}\right)$ correlated strongly with improvement of bone mineral density in the hip $(P<0.001)$ and lumbar spine $(P<0.001)$. Both baseline levels and changes during the study of IL-6 and erythrocyte sedimentation rate were correlated positively $(P<0.001)$. HRT for 2 years resulted in an increase of the bone anabolic factor, insulinlike growth factor $1(\mathrm{IGF}-1)(P<0.05)$ and a decrease of serum

levels of soluble IL-6 receptor (sIL-6R) $(P<0.05)$, which is known to enhance the biological activity of IL-6, an osteoclast-stimulating and proinflammatory cytokine. Baseline levels of IL-6 and IGF-1 were inversely associated $(P<0.05)$, and elevation of IGF-1 was connected with decrease in erythrocyte sedimentation rate $(P<0.05)$ after 2 years. Interestingly, increase in serum levels of $\mathrm{E}_{2}$ was associated with reduction of sIL-6R $(P<0.05)$ and reduction of slL-6R was correlated with improved bone mineral density in the lumbar spine $(P<0.05)$. The latter association was however not significant after adjusting for the effect of $E_{2}$ $(P=0.075)$. The influences of IGF-1 and the IL-6/sIL-6R pathways suggest possible mechanisms whereby HRT may exert beneficial effects in RA. However, to confirm this hypothesis future and larger studies are needed.
\end{abstract}

Keywords: cytokines, estrogen, hormone replacement therapy, insulin-like growth factor 1, rheumatoid arthritis

\section{Introduction}

Three different types of skeletal complications occur in rheumatoid arthritis (RA): focal erosions of marginal and subchondral bone, juxta-articular osteoporosis, and generalized bone loss. New evidence points towards common mechanisms underlying the effects on the skeleton in RA, with osteoclasts as the key mediators. Recently the RANKL/OPG/RANK (receptor activator of nuclear factor $\mathrm{KB}$ ligand/osteoprotegerin/receptor activator of nuclear factor $\mathrm{KB}$ ) system was discovered; this system modifies osteoclast precursors and the differentiation and activation of osteoclasts. OPG, which is a decoy receptor, blocks the osteoclastogenesis effects of RANKL. RANKL, OPG, and RANK act in a network of osteoclaststimulating cytokines and systemic hormones such as estrogen, $1,25(\mathrm{OH})_{2} \mathrm{D}_{3}$, and parathyroid hormone [1].

Estrogen deficiency is known to increase bone remodeling and resorption, which subsequently leads to an increased risk of osteoporosis. Hormone replacement therapy (HRT)

$\mathrm{BMD}=$ bone mineral density; $\mathrm{E}_{2}=$ estradiol; $\mathrm{ELISA}=$ enzyme-linked immunosorbent assay; $\mathrm{ESR}=$ erythrocyte sedimentation rate; $\mathrm{GH}=$ growth hormone; HRT = hormone replacement therapy; IGF-1 = insulin-like growth factor 1; IL = interleukin; IL-1Ra = IL-1-receptor antagonist; OPG = osteoprotegerin; RA = rheumatoid arthritis; RANK = receptor activator of nuclear factor $\mathrm{\kappa B} ; \mathrm{RANKL}=$ receptor activator of nuclear factor $\mathrm{KB}$ ligand; sIL-6R $=$ soluble IL- 6 receptor; TNF- $\alpha=$ tumor necrosis factor $\alpha$. 
is known to restore this imbalance. Receptors for the sex steroids estrogen, androgen, and progesterone have been shown to be expressed in the osteoblasts and osteoclasts [2]. Estrogen, besides having direct effects on bone cells, also acts indirectly, by modulating the production of osteoclast-stimulating and -inhibiting factors by paracrine substances from bone marrow cells and by the osteoblasts [2]. Estrogen also influences the skeleton through the endocrine system, increasing the production of insulin-like growth factor 1 (IGF-1), which has anabolic effects on bone $[3,4]$.

The effects of sex hormones on rheumatic diseases are controversial. Some data suggest that estrogens and HRT may be beneficial in RA [5-7], whereas other findings did not show amelioration of disease activity by HRT [8]. The peak incidence of RA in women coincides with the perimenopausal age, suggesting a connection with hormonal alterations [9]. Furthermore, type-II-collagen-induced arthritis in female mice is exacerbated by ovariectomy and is ameliorated by subsequent treatment with estradiol $\left(E_{2}\right)$ [10]. In a recent trial exploring the effects of HRT in RA, we found ameliorating effects on clinical measures of disease activity and inflammation, improved bone mineral density (BMD), and also results pointing towards retardation of joint damage [11].

The aim of this study was to assess the effects of HRT on serum levels of the osteoclast-stimulating cytokines, tumor necrosis factor $\alpha$ (TNF- $\alpha)$, IL-I $\beta$, IL- 6 , on their modifiers IL-1-receptor antagonist (IL-1Ra) and soluble IL-6 receptor (sIL-6R), on OPG, and on IGF-1, attempting to understand the mechanisms through which HRT exerts its effects in postmenopausal women with RA.

\section{Materials and methods \\ Patients}

Eighty-eight postmenopausal women with RA aged 45-65 years were included in a 2-year, randomized, single-blind, controlled study. The included patients had an active disease that met at least two of the following criteria: $\geq 6$ painful joints, $\geq 3$ swollen joints, erythrocyte sedimentation rate $(E S R) \geq 20 \mathrm{~mm}$ per hour, and C-reactive protein $\geq 10 \mathrm{mg} / \mathrm{l}$ and they also fulfilled the American Rheumatism Association 1987 revised criteria for adult RA [12]. A maximum daily dose of $7.5 \mathrm{mg}$ of prednisolone was accepted and intra-articular and intramuscular glucocorticosteroid injections were allowed during the study period. All patients gave their informed consent, and the Ethics Committee at the University of Göteborg approved the study.

\section{Treatment}

Patients were assigned by the gynecologists to one of two treatment groups, the HRT group or the control group, by simple randomization. All patients were treated with a daily dose of $500 \mathrm{mg}$ calcium and $400 \mathrm{IU}$ vitamin $\mathrm{D}_{3}$. Women in the HRT group who were more than 2 years postmenopausal were given continuous treatment with $2 \mathrm{mg}$ $E_{2}$ plus $1 \mathrm{mg}$ norethisterone acetate daily; those with a previous hysterectomy were given just $2 \mathrm{mg} \mathrm{E}_{2}$, and the remaining women were given $2 \mathrm{mg} \mathrm{E}_{2}$ for 12 days, then $2 \mathrm{mg} \mathrm{E}_{2}$ plus $1 \mathrm{mg}$ norethisterone acetate for 10 days, and then $1 \mathrm{mg} \mathrm{E} \mathrm{E}_{2}$ for 6 days. The investigators in the rheumatology departments were blinded to the identity of the treatments given. Regular medication for RA could be altered by the clinician but not by the investigator.

\section{Assessment of outcome variables}

Venous blood samples were obtained on entry into the study and after 12 and 24 months, in the morning after an overnight fast, and were stored at $-70^{\circ} \mathrm{C}$ until the time of analysis. Quantitative sandwich ELISA kits were used for measurements of TNF- $\alpha$, IL-I $\beta$, IL-1Ra, IL-6, sIL-6R (Quantikine ${ }^{\circledR}$ HS, R\&D Systems, Minneapolis, MO, USA), and OPG (Immundiagnostic, Bensheim, Germany). Radioimmunoassay was used for the quantitative determination of IGF-1 (Mediagnost, Tübingen, Germany). The sensitivities of the assays were as follows: TNF- $\alpha, 0.18 \mathrm{pg} / \mathrm{ml}$; IL-I $0.1 \mathrm{pg} / \mathrm{ml} ; \quad I L-1 R a, 14 \mathrm{pg} / \mathrm{ml} ; \quad I L-6, \quad 0.7 \mathrm{pg} / \mathrm{ml} ;$ slL-6R, $6.5 \mathrm{pg} / \mathrm{ml}$; OPG, $4 \mathrm{pg} / \mathrm{ml}$; and IGF-1, $0.02 \mathrm{ng} / \mathrm{ml}$. Samples from all time points were analyzed simultaneously. Rheumatoid factor and ESR were measured using standard laboratory techniques.

The gynecologists examined all patients for safety variables on their entry into the study and after 12 and 24 months, using vaginal ultrasonography and cytology. $E_{2}$ in serum was measured (approximately 12 hours after tablet intake) by radioimmunoassay (Clinical AssaysTM, DiaSorin, Vercelli, Italy) at baseline and yearly thereafter.

BMD in the left total hip and lumbar spine was measured by dual-energy $x$-ray absorptiometry (DXA) with Hologic QDR-4500A (Hologic ${ }^{\circledR}$, Bedford, MA, USA) at the patient's entry into the study and after 12 and 24 months.

\section{Statistical analysis}

Nonparametric tests were used, because the data were not normally distributed. Groups were compared using the Mann-Whitney $U$ test. The Wilcoxon rank sum test was used to analyze the changes within the treatment groups. Associations between cytokines, OPG, and IGF-1 were assessed by the Spearman rank correlation test. Comparisons of two proportions were tested by Fisher's exact test. All tests were two-tailed and $P \leq 0.05$ was considered statistically significant.

\section{Results}

\section{Patient population}

Forty-one patients were randomized to the HRT group and 47 to the control group. The continuously combined 
Table 1

\begin{tabular}{|c|c|c|}
\hline Characteristic & HRT group & Control group \\
\hline Age (years) & $57.0 \pm 0.9(41)$ & $58.1 \pm 0.7(47)$ \\
\hline Disease duration (years) & $16.4 \pm 1.9(41)$ & $15.5 \pm 1.7(47)$ \\
\hline Years after menopause & $8.4 \pm 1.0(36)$ & $8.3 \pm 0.8(42)$ \\
\hline $\begin{array}{l}\text { Disease-modifying antirheumatic } \\
\text { drugs }\end{array}$ & $83 \%(41)$ & $79 \%(47)$ \\
\hline Glucocorticosteroid treatment & $24 \%(41)$ & $19 \%(47)$ \\
\hline $\begin{array}{l}\text { Nonsteroidal anti-inflammatory } \\
\text { drugs }\end{array}$ & $78 \%(41)$ & $77 \%(47)$ \\
\hline $\begin{array}{l}\text { Positive serum test for rheumatoid } \\
\text { factor }\end{array}$ & $83 \%(40)$ & $85 \%(47)$ \\
\hline Serum TNF- $\alpha$ (pg/ml) & $4.0 \pm 0.4(39)$ & $4.4 \pm 0.5(46)$ \\
\hline Serum IL-1Ra (pg/ml) & $608 \pm 123(40)$ & $485 \pm 74(47)$ \\
\hline Serum IL-6 (pg/ml) & $23.8 \pm 5.7(40)$ & $22.4 \pm 4.1(47)$ \\
\hline Serum slL-6R (pg/ml) & $822 \pm 42$ (39) & $762 \pm 31(47)$ \\
\hline Serum OPG (pg/ml) & $113 \pm 18(37)$ & $112 \pm 12.8(46)$ \\
\hline Serum IGF-1 (ng/ml) & $81.7 \pm 4.4(34)$ & $78.2 \pm 5.0(43)$ \\
\hline $\mathrm{ESR}(\mathrm{mm})$ & $30.8 \pm 3.0(41)$ & $26.5 \pm 2.2(46)$ \\
\hline Serum estradiol (pmol/l) & $47.7 \pm 8.6(31)$ & $37.2 \pm 4.0(40)$ \\
\hline
\end{tabular}

Values not shown as percentages are means \pm standard error of the mean. Numbers of patients for whom data were available are shown in parentheses. ESR = erythrocyte sedimentation rate; IGF-1 = insulinlike growth factor $1 ; \mathrm{IL}-1 \mathrm{Ra}=\mathrm{IL}-1$-receptor antagonist; OPG $=$ osteoprotegerin; sIL-6R $=$ soluble IL- 6 receptor; TNF- $\alpha=$ tumor necrosis factor $\alpha$.

regimen of HRT was given to 23 patients, sequential treatment to 14 , and $E_{2}$ alone to 4 who had undergone hysterectomy.

There were no significant differences in baseline characteristics between the study groups (Table 1). On entry to the study, 71 patients $(81 \%)$ were taking disease-modifying antirheumatic drugs. Methotrexate predominated and was used by 30 women (34\%). Nineteen (22\%) of the patients were given corticosteroids at a mean dosage of $4.6 \mathrm{mg}$ of prednisolone and $68(77 \%)$ were given nonsteroidal anti-inflammatory drugs. The proportions of patients given disease-modifying antirheumatic drugs, methotrexate, nonsteroidal anti-inflammatory drugs, and corticosteroids were equal in the HRT and control groups at all check points.

Six patients in the HRT group and two in the control group withdrew from the study before completing the 2 years. No serious side effects were observed [11]. Data for samples taken were too small to permit all analyses to be made or samples were missing. The numbers of patients with available data are presented in Tables 1 and 2. There were more missing samples in the HRT group than in the controls regarding OPG analyses $(P=0.044)$ but not for any of the other biological factors.

\section{Serum concentrations and correlations at baseline}

The serum concentrations at baseline of TNF- $\alpha, \mathrm{IL}-1 \mathrm{Ra}$, IL-6, slL-6R, OPG, and IGF-1 are shown in Table 1. No significant differences were noticed at entry into the study between the HRT and control groups. Because the IL-I $\beta$ levels were below the detection threshold in $49 \%$ of participants, they were not considered to be reliable and are not reported.

As shown in Table 3, serum levels of slL-6R correlated significantly with levels of IL- $6, \mathrm{TNF}-\alpha$, and IL-1Ra at baseline. IL-6 in serum was highly associated with ESR (Fig. 1a) and, to a smaller degree, was inversely associated with IGF-1. TNF- $\alpha$ was also significantly connected with IL-1Ra. No significant associations were seen between serum levels of $E_{2}$ and OPG and the proinflammatory cytokines. However, $\mathrm{E}_{2}$ was positively associated with $\mathrm{BMD}$ at the lumbar spine $(P=0.033)$ at baseline.

\section{The impact of HRT}

The serum levels of the cytokines, OPG, IGF-1, ESR, and $E_{2}$ at baseline and after 12 and 24 months treatment from patients with both baseline and 24-month data available with corresponding 12-month data are presented in Table 2. No significant differences between the HRT and control groups were observed at entry into the study.

Serum levels of sIL-6R, acting as an agonist to IL-6, were suppressed significantly in the HRT group after 12 and 24 months. The levels of IL-6 were not altered in any group during the trial.

IGF-1, exerting anabolic effects on bone, increased significantly in the HRT group after 2 years, while it remained unchanged in the control group.

OPG increased significantly during the first year in the HRT group compared with the controls, but the increase did not persist throughout the investigation.

IL-1 Ra, an inhibitor of IL-1, increased significantly the first year, in both the HRT and control groups, but no significant differences were seen after 24 months between or within these groups. The mean value of IL-1Ra in Table 1 is higher than the value at baseline of patients who were followed up for the whole study period. The discrepancy, which was not significant, was due to an outlier, with a very high baseline IL-1Ra level $(5105 \mathrm{pg} / \mathrm{ml})$, who withdrew from the investigation due to nausea. 
Table 2

\begin{tabular}{|c|c|c|c|c|c|c|}
\hline \multirow[b]{2}{*}{ Laboratory test } & \multicolumn{3}{|c|}{ HRT } & \multicolumn{3}{|c|}{ Controls } \\
\hline & Baseline & 12 months & 24 months & Baseline & 12 months & 24 months \\
\hline Serum TNF- $\alpha$ (pg/ml) & $4.1 \pm 0.4(32)$ & $3.8 \pm 0.4(30)$ & $3.6 \pm 0.4(32)$ & $4.4 \pm 0.5(44)$ & $4.1 \pm 0.3(43)$ & $4.2 \pm 0.4(44)$ \\
\hline Serum IL-1Ra (pg/ml) & $501 \pm 49$ (35) & $678 \pm 82(32)^{+t}$ & $558 \pm 85(35)$ & $494 \pm 77(45)$ & $596 \pm 104(45)^{\dagger}$ & $606 \pm 128$ \\
\hline Serum IL-6 (pg/ml) & $25.7 \pm 6.3(35)$ & $25.1 \pm 8.3(32)$ & $23.1 \pm 5.2(35)$ & $23.2 \pm 4.3(45)$ & $27.1 \pm 4.5(45)$ & $25.6 \pm 5.4(45)$ \\
\hline Serum slL-6R (pg/ml) & $851 \pm 46(34)$ & $801 \pm 41(31)^{\ddagger}$ & $790 \pm 36(34)^{\dagger, \neq}$ & $771 \pm 31(45)$ & $794 \pm 35(45)$ & $804 \pm 34(45)$ \\
\hline Serum OPG (pg/ml) & $104 \pm 19$ (30) & $133 \pm 29(28)^{\ddagger}$ & $112 \pm 19(30)$ & $114 \pm 14(43)$ & $109 \pm 13(43)$ & $120 \pm 13(43)$ \\
\hline Serum IGF-1 (ng/ml) & $80.3 \pm 4.9(29)$ & $81.0 \pm 4.0(24)$ & $92.6 \pm 4.6(29)^{\ddagger}$ & $78.6 \pm 5.3(40)$ & $78.3 \pm 5.0(40)$ & $77.7 \pm 3.9(40)$ \\
\hline $\mathrm{ESR}(\mathrm{mm})$ & $32.5 \pm 3.2(35)$ & $29.0 \pm 3.2(35)$ & $24.3 \pm 2.2(35)^{+t, \neq}$ & $27.3 \pm 2.3(43)$ & $26.6 \pm 2.9(41)$ & $26.7 \pm 2.7(43)$ \\
\hline Serum estradiol (pmol/l) & $44.4 \pm 8.6(27)$ & $176.7 \pm 31.4(22)^{++1,+\# \#}$ & 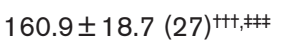 & $38.0 \pm 4.4(36)$ & $39,0 \pm 5,9(36)$ & $38,9 \pm 6,6(36)$ \\
\hline
\end{tabular}

Results for patients with both baseline and 24-month data available with corresponding 12-month data are shown. Values are means \pm standard error of the mean. Numbers of patients for whom data were available are shown in parentheses. For comparison with baseline, ${ }^{\dagger} P \leq 0.05,{ }^{\dagger+} P<0.01$, ${ }^{+t+} P<0.001$. For comparison with controls from baseline, ${ }^{\ddagger} P \leq 0.05,{ }^{\#} P<0.01,{ }^{\# \neq} P<0.001$. ESR $=$ erythrocyte sedimentation rate; IGF-1 $=$ insulinlike growth factor 1 ; IL-1Ra $=\mathrm{IL}-1$-receptor antagonist; OPG $=$ osteoprotegerin; slL-6R = soluble IL-6 receptor; TNF- $\alpha=$ tumor necrosis factor $\alpha$.

Table 3

\begin{tabular}{|c|c|c|c|c|c|c|c|}
\hline Test & TNF- $\alpha$ & IL-1Ra & $\mathrm{IL}-6$ & sIL-6R & IGF-1 & ESR & Estradiol \\
\hline Serum TNF- $\alpha$ (pg/ml) & - & $0.259^{*}$ & 0.041 & $0.346^{\star \star}$ & -0.128 & 0.135 & -0.042 \\
\hline Serum IL-1Ra (pg/ml) & $0.259^{*}$ & - & $0.338^{\star \star}$ & $0.434^{\star \star \star}$ & -0.021 & 0.108 & 0.088 \\
\hline Serum IL-6 (pg/ml) & 0.041 & $0.338^{\star \star}$ & - & $0.261^{*}$ & $-0.245^{\star}$ & $0.470^{\star \star \star}$ & 0.116 \\
\hline Serum slL-6R (pg/ml) & $0.346^{\star *}$ & $0.434^{\star \star \star}$ & $0.261^{*}$ & - & -0.207 & 0.115 & 0.145 \\
\hline Serum IGF-1 (ng/ml) & -0.128 & -0.021 & $-0.245^{\star}$ & -0.207 & - & -0.177 & 0.014 \\
\hline $\mathrm{ESR}(\mathrm{mm})$ & 0.135 & 0.108 & $0.470^{\star \star \star}$ & 0.115 & -0.177 & - & 0.015 \\
\hline Serum estradiol (pmol/l) & -0.042 & 0.088 & 0.116 & 0.145 & 0.014 & 0.015 & - \\
\hline
\end{tabular}

${ }^{\star} P<0.05,{ }^{\star \star} P<0.01,{ }^{\star \star \star} P<0.001$. ESR $=$ erythrocyte sedimentation rate; IGF-1 = insulin-like growth factor $1 ; \mathrm{IL}-1 \mathrm{Ra}=\mathrm{IL}-1$-receptor antagonist; slL-6R $=$ soluble IL- 6 receptor; TNF- $\alpha=$ tumor necrosis factor $\alpha$.

TNF- $\alpha$, a mediator of inflammation and joint destruction in RA, did not alter significantly during the study in any group.

As described elsewhere, BMD improved in the total hip and lumbar spine $(P<0.001)$ in the HRT group, while it decreased slightly in the controls [11].

\section{Correlations between changes of variables from baseline to 24 months}

In order to further confirm the above findings about the effects of HRT and to investigate associations between the diverse variables, correlation analyses of changes from baseline to 24 months in serum levels of TNF- $\alpha, I L-1 R a$, IL-6, sIL-6R, OPG, IGF-1, ESR, and $E_{2}$ and changes of $B M D$ in the total hip and lumbar spine were sought. The results are shown in Table 4, except for OPG, which was not associated with any of the other factors.
Increase in serum levels of $E_{2}$ correlated strongly with improvement of BMD in the hip and lumbar spine and to a lower degree with reduction of sIL-6R. The alteration in slL-6R was inversely associated with change in BMD in the lumbar spine. To find out if there was an independent correlation between sIL-6R and BMD in the lumbar spine, we calculated the partial correlation coefficient adjusting for the $E_{2}$ changes. The coefficient altered somewhat, from $-0.270(P=0.015)$ to a no longer significant level, $-0.234(P=0.075)$.

Just as in the case of the baseline correlations, there were strong associations between the changes in serum levels of IL-6 and ESR (Fig. 1b) and of IL-6 and IL-1Ra. Increased serum levels of $E_{2}$ were correlated with reduction of sIL-6R and TNF- $\alpha$. The change in TNF- $\alpha$ was also positively correlated with changes in IL-1Ra, ESR, and to 


\section{Figure 1}

(a)

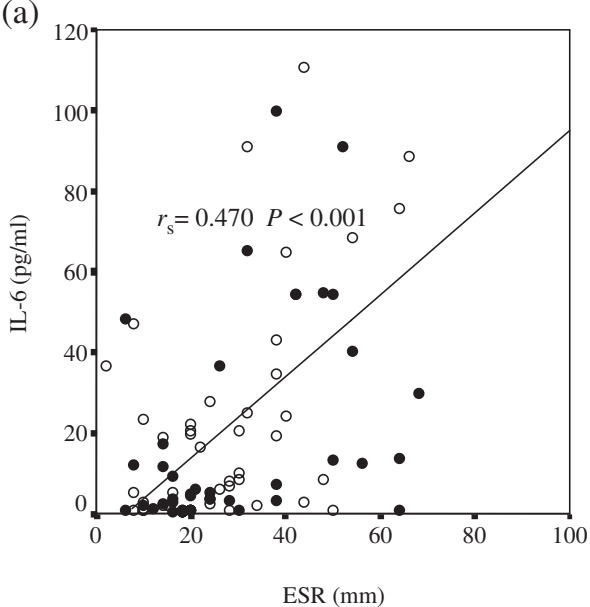

(b)
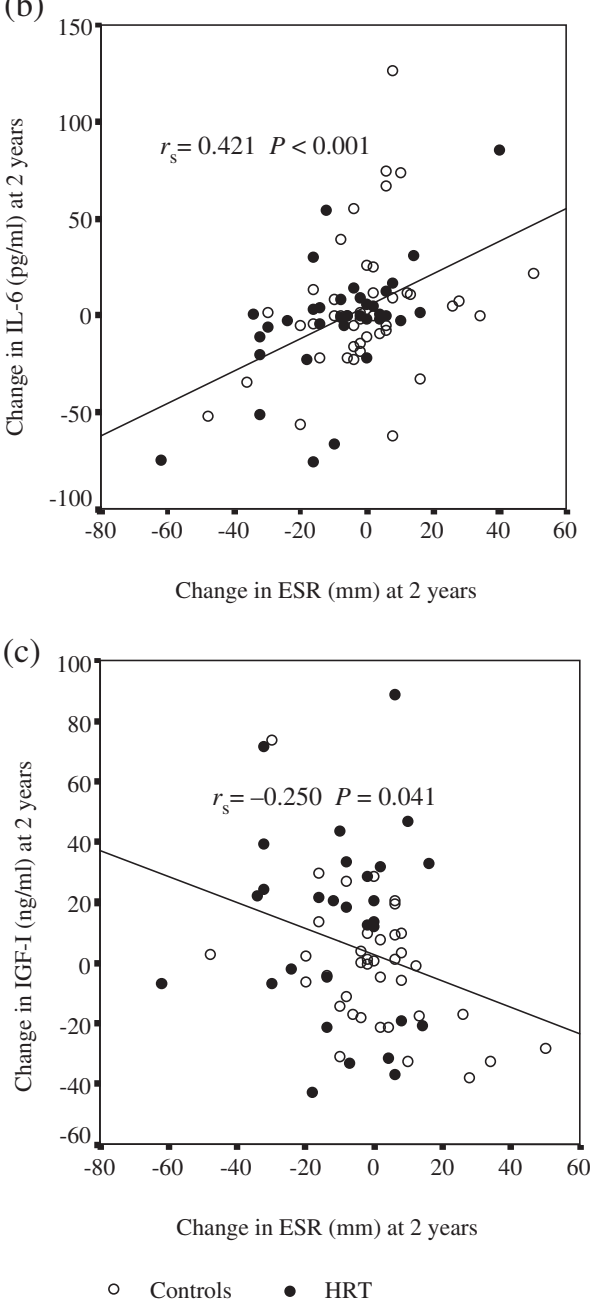

Effects of HRT in postmenopausal women with rheumatoid arthritis. The associations between (a) baseline levels of erythrocyte sedimentation rate (ESR) and interleukin-6 (IL-6), (b) the changes in ESR and IL-6 after 2-year follow-up, and (c) the changes in ESR and IGF-1 after 2-year follow-up are shown in scattergram plots. Spearman rank correlation coefficients $\left(r_{s}\right)$ and $P$ values are given. a minor extent in sIL-6R and was inversely correlated with the change in IGF-1. The alteration in ESR was to a small degree inversely associated with change in IGF-1 (Fig. 1c).

\section{Discussion}

We have recently reported that 2 years of HRT in postmenopausal women with RA showed signs of decreased laboratory measures of inflammation, resulting in a better disease activity score 28 (DAS 28) response, improved $B M D$, and indicated a protective effect on joint destruction [11]. The objective of the present study was to analyze possible mechanisms behind the effects of HRT in postmenopausal patients with long-lasting and active RA.

HRT acts in a complex, not yet completely elucidated way and there are several possible routes whereby HRT could influence the erosive process and juxta-articular and generalized osteoporosis in RA. Expression of estrogen receptor in human osteoblastic cells was shown in 1988 [13] and in osteoclastic cells in 1991 [14]. Besides having the capacity to decrease osteoclast formation and activity and to increase apoptosis of osteoclasts $[15,16]$, estrogen also seems to have a stimulatory effect on bone formation by the osteoblasts $[17,18]$. Thus, estrogen seems to have both anti-proliferative and proliferative effects. In addition to these direct effects on bone cells, the major action of estrogens in vivo is believed to be mostly by indirect actions, regulation of growth factors and cytokines in osteoblasts, which in turn regulate osteoclast differentiation and activation [2]. Among these factors, we analyzed IL-I $\beta$, IL-6, TNF- $\alpha$, all inducers of bone resorption [19], and the decoy receptor OPG, inhibiting activation of osteoclasts and its precursors [20], as well as the bioactivity modifiers IL-1Ra and sIL-6R and the endocrine bone-stimulating agent IGF-1.

IL-6 is one of the key mediators of increased bone loss in postmenopausal women. Production of this cytokine by mononuclear blood cells increases with age and menopause [21] and is inhibited in vitro by $\mathrm{E}_{2}$ [22].The bioactivity of IL- 6 is significantly enhanced in the presence of its agonist, sIL-6R, which renders cells expressing the gp 130 signaling protein responsive to IL-6 [23]. Therefore, it is suggested that sIL-6R may be of more importance than IL- 6 in the postmenopausal acceleration of bone turnover $[24,25]$. IL-6/sIL-6R are also believed to be involved in joint destruction through osteoclastogenesis in RA [26]. We have recently reported that the radiographic scores of the women with RA showed a significant positive correlation with IL-6 and sIL-6R [27]. In this study, serum levels of slL-6R decreased significantly in the HRT group. Furthermore, the change in $E_{2}$ in serum was inversely, though modestly, correlated with the change in slL-6R. The change of slL-6R was inversely associated with increase in BMD in the lumbar spine after 2 years. 


\begin{tabular}{|c|c|c|c|c|c|c|c|c|c|}
\hline Test & TNF- $\alpha$ & IL-1Ra & IL-6 & sIL-6R & IGF-1 & ESR & Estradiol & $\begin{array}{l}\text { BMD } \\
\text { total hip }\end{array}$ & $\begin{array}{l}\text { BMD } \\
\text { lumbar } \\
\text { spine }\end{array}$ \\
\hline Serum TNF- $\alpha$ (pg/ml) & - & $0.303^{\star \star}$ & 0.108 & $0.245^{\star}$ & $-0.258^{*}$ & $0.310^{\star \star}$ & $-0.263^{*}$ & 0.169 & -0.132 \\
\hline Serum IL-1Ra (pg/ml) & $0.303^{\star \star}$ & - & $0.313^{\star \star}$ & 0.050 & -0.222 & 0.122 & 0.012 & 0.075 & -0.126 \\
\hline Serum IL-6 (pg/ml) & 0.108 & $0.313^{\star \star}$ & - & 0.041 & -0.061 & $0.421^{\star \star \star}$ & 0.188 & 0.081 & 0.078 \\
\hline Serum slL-6R (pg/ml) & $0.245^{\star}$ & 0.050 & 0.041 & - & -0.137 & 0.119 & $-0.263^{\star}$ & -0.132 & $-0.278^{\star}$ \\
\hline Serum IGF-1 (ng/ml) & $-0.258^{*}$ & -0.222 & -0.061 & -0.137 & - & $-0.250^{*}$ & 0.179 & 0.200 & 0.195 \\
\hline $\mathrm{ESR}(\mathrm{mm})$ & $0.310^{\star *}$ & 0.122 & $0.421^{\star \star \star}$ & 0.119 & $-0.250^{*}$ & - & -0.079 & -0.092 & -0.145 \\
\hline Serum estradiol (pmol/l) & $-0.263^{\star}$ & 0.012 & 0.188 & $-0.263^{*}$ & 0.179 & -0.079 & - & $0.491^{\star \star \star}$ & $0.483^{\star \star \star}$ \\
\hline
\end{tabular}

${ }^{\star} P<0.05,{ }^{* \star} P<0.01,{ }^{* \star *} P<0.001 . \mathrm{BMD}=$ bone mineral density; ESR $=$ erythrocyte sedimentation rate; IGF-1 = insulin-like growth factor 1 ; $\mathrm{IL}-1 \mathrm{Ra}=\mathrm{IL}-1$-receptor antagonist; sIL-6R $=$ soluble IL-6 receptor; TNF- $\alpha=$ tumor necrosis factor $\alpha$.

Since the increase of $E_{2}$ in serum was significantly correlated with improvement of BMD in the lumbar spine and total hip, we adjusted the correlation of slL-6R and bone mass in the spine for the effect of changed $\mathrm{E}_{2}$ levels. After adjustment, the association was no longer significant $(P=0.075)$. However the partial correlation coefficient changed only slightly, indicating the possibility of a true correlation between sIL-6R and bone mass in the spine.

In sum, we suggest that estrogen-mediated effects of IL-6/sIL-6R functions may be involved in the protection of the skeleton in RA patients.

Growth hormone $(\mathrm{GH})$ contributes also in the regulation of bone metabolism: a deficiency of this hormone causes reduced $B M D$ and replacement therapy has been shown to increase bone mass [3]. GH is the primary inducer of IGF-1 synthesis by the liver and a central regulator of the concentration of circulating IGF-1 [3]. IGF-1 has been found to induce cellular proliferation and has an antiapoptotic effect [28]. Estrogen stimulates the secretion of GH from the pituitary gland [29] and also increases the production of IGF-1 by osteoblastic cell lines [30]. In the present investigation, HRT resulted in a significant increase in serum levels of IGF-1. We did not find a significant association between the changes in $E_{2}$ levels and IGF-1 after 2 years, which might be caused by the limited number of patients examined.

It has also been reported that IGF-1 is reduced in inflammatory diseases such as juvenile chronic arthritis (JCA) and RA [31,32], and treating JCA with human growth hormone increased IGF-1, growth velocity, and markers of bone formation [31]. Furthermore, De Benedetti and colleagues proposed that IL- 6 mediated the decrease in IGF-1 production that was associated with growth defect in transgenic mice and they also showed that circulating IL-6 levels were negatively correlated with IGF-1 levels in JCA [33]. We also found in this study an inverse correlation between IL- 6 and IGF-1, although the $P$ value (0.032) was relatively weak and serum levels of IGF-1 were only half of the reference values of age-matched healthy postmenopausal women [34]. There was also a strong positive correlation between ESR and IL-6 at baseline, which has previously been observed [35], and, interestingly, the change of ESR during the course of the study was highly correlated with the change of IL- 6 and to a lesser degree was inversely correlated with the change of IGF-1. However, it is unclear if the increase of IGF- 1 in this trial is caused by estrogen-mediated reduction of the IL-6/sIL-6R pathway or by effects on the GH/IGF-1 axis or by a combination of these mechanisms.

Administration of IL-1Ra or anti-TNF treatment has recently been found to reduce radiological progression in RA $[36,37]$. These cytokines and their receptors have also been reported to be involved in bone loss after estrogen deficiency: for instance, administration of IL-1Ra and TNFbinding protein (TNFbp), an inhibitor of TNF, to ovariectomized mice decreased osteoclastogenesis and bone resorption [38]. It was also reported that estrogen replacement in women induced reduction of IL-1 and TNF- $\alpha$ in peripheral blood mononuclear cells [39], whereas other researchers did not observe any effect of HRT on serum levels of the cytokines [40]. In our trial, serum levels of TNF- $\alpha$ were not significantly altered in any group, but we found a weak inverse correlation between the changes in TNF- $\alpha$ and $E_{2}$ after 2 years. The change in TNF- $\alpha$ was also associated weakly with the change in slL-6R and more strongly with the alterations in IL-1Ra and ESR and inversely to a smaller extent with the change in IGF-1. 
IL-1Ra increased significantly during the first year in both study groups, but the rise was not sustained until the end of the trial. One hypothesis to explain this finding is that vitamin $D_{3}$, which affects the immune system [41] and was given to all the women studied, may have affected the production of IL-1Ra. We could not tell if HRT had any effect on IL-1 $\beta$, since half of the participants had undetectable levels.

We were also interested in the effects of HRT on OPG, since treatment with OPG in rat adjuvant arthritis blocked bone and cartilage destruction [42] and $17 \beta$-estradiol has been shown to increase OPG mRNA and protein levels in human osteoblastic cell lines [43], whereas other workers did not find that OPG was regulated by estrogen [44]. In the present study, OPG increased significantly during the first year in the HRT group compared with the controls. There is a need to be cautious in interpreting this finding, since there were significantly more missing OPG samples in the HRT group and no associations between OPG and the other variables were discovered.

The present study has certain limitations. Corrections for multiple comparisons have not been made, since the findings seem biologically reasonable. Yet, one needs to be cautious about significances with $P$ values at the $<0.05$ level, which theoretically could have occurred by chance, because quite a lot of tests have been performed. In addition, there were unfortunately some missing samples, in particular from the HRT group, a circumstance that renders some of the data incomplete.

Most of the women in the HRT group received combined treatment with $\mathrm{E}_{2}$ plus norethisterone acetate continuously or sequentially. Consequently, our findings show the effects of both substances. However, the change in $E_{2}$ alone correlated strongly with the improvement of BMD in the total hip and lumbar spine. Our discussion relates mostly to previous findings in HRT and estrogen investigations, because less is known about the effects of progestogen on the immune and endocrine systems. However, progestogens, like androgens, are known to have immunosuppressive effects, and during pregnancy, progesterone acts together with estrogen and cortisol to influence alterations in immunological reactivity, such as decreasing cytokines associated with T-helper- 1 cells and increasing those associated with T-helper- 2 cells, phenomena that are probably connected with the clinical improvement in RA $[45,46]$.

\section{Conclusion}

In summary, we found in this controlled clinical trial that the increase of $E_{2}$ levels in serum was highly correlated with improved BMD. We have tried to elucidate possible ways, in the network of proinflammatory cytokines and IGF-1, by which HRT exerts its effects on the skeleton in levels of sIL-6R, whereas IGF-1 levels were observed to be increased. Both of these results - the effects on the IL-6/ slL-6R pathway and on IGF-1 in the endocrine system - may be involved in the mechanisms mediating the beneficial effects of HRT. There is a need for larger, controlled, longterm studies of combined treatment in RA - estrogen plus progestogen, and estrogen alone - to support our results and to investigate the effects of the various hormones.

\section{Competing interests}

None declared.

\section{Acknowledgements}

Supported by grants from Regional Research Sources from Västra Götaland, Novo Nordisk Research Foundation, Rune och Ulla Amlövs Foundation for Rheumatology Research, the Research Foundation of Trygg-Hansa, the Swedish and Göteborg Association against Rheumatism, Reumaforskningsfond Margareta, King Gustav V:s 80-years Foundation, the Medical Society of Göteborg, and the Medical Faculty of Göteborg (LUA). We thank Nycomed for providing the calcium and vitamin $\mathrm{D}_{3}$ used in the study. We thank Maud Pettersson and Lena Svensson for their laboratory help and Anders Oden for statistical advice.

\section{References}

1. Romas E, Gillespie MT, Martin TJ: Involvement of receptor activator of NFkappaB ligand and tumor necrosis factor-alpha in bone destruction in rheumatoid arthritis. Bone 2002, 30:340346.

2. Spelsberg TC, Subramaniam M, Riggs BL, Khosla S: The actions and interactions of sex steroids and growth factors/cytokines on the skeleton. Mol Endocrinol 1999, 13:819-828.

3. Ohlsson C, Bengtsson BA, Isaksson OG, Andreassen TT, Slootweg MC: Growth hormone and bone. Endocr Rev 1998, 19:55-79.

4. Riggs BL, Khosla S, Melton LJ, 3rd: Sex steroids and the construction and conservation of the adult skeleton. Endocr Rev 2002, 23:279-302.

5. Ostensen $\mathrm{M}$ : Sex hormones and pregnancy in rheumatoid arthritis and systemic lupus erythematosus. Ann NY Acad Sci 1999, 876:131-143.

6. Brennan P, Bankhead C, Silman A, Symmons D: Oral contraceptives and rheumatoid arthritis: results from a primary carebased incident case-control study. Semin Arthritis Rheum 1997, 26:817-823.

7. Hall GM, Daniels M, Huskisson EC, Spector TD: A randomised controlled trial of the effect of hormone replacement therapy on disease activity in postmenopausal rheumatoid arthritis. Ann Rheum Dis 1994, 53:112-116.

8. van den Brink HR, van Everdingen AA, van Wijk MJ, Jacobs JW, Bijlsma JW: Adjuvant oestrogen therapy does not improve disease activity in postmenopausal patients with rheumatoid arthritis. Ann Rheum Dis 1993, 52:862-865.

9. Goemaere S, Ackerman C, Goethals K, De Keyser F, Van der Straeten C, Verbruggen G, Mielants H, Veys EM: Onset of symptoms of rheumatoid arthritis in relation to age, sex and menopausal transition. J Rheumatol 1990, 17:1620-1622.

10. Holmdahl R, Jansson L, Meyerson B, Klareskog L: Oestrogen induced suppression of collagen arthritis: I. Long term oestradiol treatment of DBA/1 mice reduces severity and incidence of arthritis and decreases the anti type II collagen immune response. Clin Exp Immunol 1987, 70:372-378.

11. Forsblad d'Elia H, Larsen A, Mattsson L-A, Waltbrand E, Kvist G, Mellström D, Saxne T, Ohlsson C, Nordborg E, Carlsten H: The impact of hormone replacement therapy on disease progression and bone mineral density in rheumatoid arthritis. J Rheumatol, in press.

12. Arnett FC, Edworthy SM, Bloch DA, McShane DJ, Fries JF, Cooper NS, Healey LA, Kaplan SR, Liang MH, Luthra HS, Medsger TA Jr, Mitchell DM, Neustadt DH, Pinals RS, Schaller JG, Sharp JT, Wilder RL, Hunder GG: The American Rheumatism Association 1987 revised criteria for the classification of rheumatoid arthritis. Arthritis Rheum 1988, 31:315-324. 
13. Eriksen EF, Colvard DS, Berg NJ, Graham ML, Mann KG, Spelsberg TC, Riggs BL: Evidence of estrogen receptors in normal human osteoblast-like cells. Science 1988, 241:84-86.

14. Oursler MJ, Osdoby P, Pyfferoen J, Riggs BL, Spelsberg TC: Avian osteoclasts as estrogen target cells. Proc Natl Acad Sci USA 1991, 88:6613-6617.

15. Hughes DE, Dai A, Tiffee JC, Li HH, Mundy GR, Boyce BF: Estrogen promotes apoptosis of murine osteoclasts mediated by TGF-beta. Nat Med 1996, 2:1132-1136.

16. Kameda T, Mano H, Yuasa T, Mori Y, Miyazawa K, Shiokawa M, Nakamaru Y, Hiroi E, Hiura K, Kameda A, Yang NN, Hakeda Y, Kumegawa M: Estrogen inhibits bone resorption by directly inducing apoptosis of the bone-resorbing osteoclasts. J Exp Med 1997, 186:489-495.

17. Chow J, Tobias JH, Colston KW, Chambers TJ: Estrogen maintains trabecular bone volume in rats not only by suppression of bone resorption but also by stimulation of bone formation. $J$ Clin Invest 1992, 89:74-78.

18. Qu Q, Perala-Heape M, Kapanen A, Dahllund J, Salo J, Vaananen HK, Harkonen P: Estrogen enhances differentiation of osteoblasts in mouse bone marrow culture. Bone 1998, 22:201-209.

19. Manolagas SC, Jilka RL: Bone marrow, cytokines, and bone remodeling. Emerging insights into the pathophysiology of osteoporosis. N Engl J Med 1995, 332:305-311.

20. Hofbauer LC, Khosla S, Dunstan CR, Lacey DL, Boyle WJ, Riggs $\mathrm{BL}$ : The roles of osteoprotegerin and osteoprotegerin ligand in the paracrine regulation of bone resorption. $J$ Bone Miner Res 2000, 15:2-12.

21. Fagiolo U, Cossarizza A, Scala E, Fanales-Belasio E, Ortolani C, Cozzi E, Monti D, Franceschi C, Paganelli R: Increased cytokine production in mononuclear cells of healthy elderly people. Eur $\mathrm{J}$ Immunol 1993, 23:2375-2378.

22. Kassem M, Harris SA, Spelsberg TC, Riggs BL: Estrogen inhibits interleukin- 6 production and gene expression in a human osteoblastic cell line with high levels of estrogen receptors. J Bone Miner Res 1996, 11:193-199.

23. Tamura T, Udagawa N, Takahashi N, Miyaura C, Tanaka S, Yamada Y, Koishihara Y, Ohsugi Y, Kumaki K, Taga T, Kishimoto T, Suda T: Soluble interleukin-6 receptor triggers osteoclast formation by interleukin 6. Proc Natl Acad Sci USA 1993, 90: 11924-11928

24. Abrahamsen B, Bonnevie-Nielsen V, Ebbesen EN, Gram J, BeckNielsen $\mathrm{H}$ : Cytokines and bone loss in a 5-year longitudinal study - hormone replacement therapy suppresses serum soluble interleukin-6 receptor and increases interleukin-1receptor antagonist: the Danish Osteoporosis Prevention Study. J Bone Miner Res 2000, 15:1545-1554.

25. Girasole G, Giuliani N, Modena AB, Passeri G, Pedrazzoni M: Oestrogens prevent the increase of human serum soluble interleukin-6 receptor induced by ovariectomy in vivo and decrease its release in human osteoblastic cells in vitro. Clin Endocrinol (Oxf) 1999, 51:801-807.

26. Kotake S, Sato K, Kim KJ, Takahashi N, Udagawa N, Nakamura I, Yamaguchi A, Kishimoto T, Suda T, Kashiwazaki S: Interleukin-6 and soluble interleukin- 6 receptors in the synovial fluids from rheumatoid arthritis patients are responsible for osteoclastlike cell formation. J Bone Miner Res 1996, 11:88-95.

27. Forsblad d'Elia H, Larsen A, Waltbrand E, Kvist G, Mellström D, Saxne T, Ohlsson C, Nordborg E, Carlsten H: Radiographic joint destruction in postmenopausal rheumatoid arthritis is strongly associated with generalized osteoporosis. Ann Rheum Dis, in press.

28. Heemskerk VH, Daemen MA, Buurman WA: Insulin-like growth factor-1 (IGF-1) and growth hormone (GH) in immunity and inflammation. Cytokine Growth Factor Rev 1999, 10:5-14.

29. Jansson JO, Eden S, Isaksson O: Sexual dimorphism in the control of growth hormone secretion. Endocr Rev 1985, 6:128150.

30. Nasu M, Sugimoto T, Kaji H, Chihara K: Estrogen modulates osteoblast proliferation and function regulated by parathyroid hormone in osteoblastic SaOS-2 cells: role of insulin-like growth factor (IGF)-I and IGF-binding protein-5. J Endocrinol 2000, 167:305-313.

31. Bechtold S, Ripperger P, Muhlbayer D, Truckenbrodt H, Hafner R, Butenandt O, Schwarz HP: GH therapy in juvenile chronic arthritis: results of a two-year controlled study on growth and bone. J Clin Endocrinol Metab 2001, 86:5737-5744.
32. Johansson AG, Baylink DJ, af Ekenstam E, Lindh E, Mohan S, Ljunghall $S$ : Circulating levels of insulin-like growth factor-I and -II, and IGF- binding protein-3 in inflammation and after parathyroid hormone infusion. Bone Miner 1994, 24:25-31.

33. De Benedetti F, Alonzi T, Moretta A, Lazzaro D, Costa P, Poli V, Martini A, Ciliberto G, Fattori E: Interleukin 6 causes growth impairment in transgenic mice through a decrease in insulinlike growth factor-I. A model for stunted growth in children with chronic inflammation. J Clin Invest 1997, 99:643-650.

34. Landin-Wilhelmsen K, Wilhelmsen L, Lappas G, Rosen T, Lindstedt G, Lundberg PA, Bengtsson BA: Serum insulin-like growth factor $I$ in a random population sample of men and women: relation to age, sex, smoking habits, coffee consumption and physical activity, blood pressure and concentrations of plasma lipids, fibrinogen, parathyroid hormone and osteocalcin. Clin Endocrinol (Oxf) 1994, 41:351-357.

35. Boss B, Neeck G: Correlation of IL-6 with the classical humoral disease activity parameters ESR and CRP and with serum cortisol, reflecting the activity of the HPA axis in active rheumatoid arthritis. Z Rheumato/ 2000, 59:1//62-64.

36. Bathon JM, Martin RW, Fleischmann RM, Tesser JR, Schiff MH, Keystone EC, Genovese MC, Wasko MC, Moreland LW, Weaver AL, Markenson J, Finck BK: A comparison of etanercept and methotrexate in patients with early rheumatoid arthritis. $N$ Engl J Med 2000, 343:1586-1593.

37. Jiang Y, Genant HK, Watt I, Cobby M, Bresnihan B, Aitchison R, McCabe D: A multicenter, double-blind, dose-ranging, randomized, placebo-controlled study of recombinant human interleukin-1 receptor antagonist in patients with rheumatoid arthritis: radiologic progression and correlation of Genant and Larsen scores. Arthritis Rheum 2000, 43:1001-1009.

38. Kitazawa R, Kimble RB, Vannice JL, Kung VT, Pacifici R: Interleukin-1 receptor antagonist and tumor necrosis factor binding protein decrease osteoclast formation and bone resorption in ovariectomized mice. J Clin Invest 1994, 94: 2397-2406.

39. Pacifici R, Brown C, Puscheck E, Friedrich E, Slatopolsky E, Maggio D, McCracken R, Avioli LV: Effect of surgical menopause and estrogen replacement on cytokine release from human blood mononuclear cells. Proc Natl Acad Sci USA 1991, 88:5134-5138.

40. Kamada M, Irahara M, Maegawa M, Ohmoto $Y$, Takeji T, Yasui T, Aono $\mathrm{T}$ : Postmenopausal changes in serum cytokine levels and hormone replacement therapy. Am J Obstet Gynecol 2001, 184:309-314.

41. Bouillon R, Okamura WH, Norman AW: Structure-function relationships in the vitamin D endocrine system. Endocr Rev 1995, 16:200-257.

42. Kong YY, Feige U, Sarosi I, Bolon B, Tafuri A, Morony S, Capparelli C, Li J, Elliott R, McCabe S, Wong T, Campagnuolo G, Moran E, Bogoch ER, Van G, Nguyen LT, Ohashi PS, Lacey DL, Fish E, Boyle WJ, Penninger JM: Activated T cells regulate bone loss and joint destruction in adjuvant arthritis through osteoprotegerin ligand. Nature 1999, 402:304-309.

43. Hofbauer LC, Khosla S, Dunstan CR, Lacey DL, Spelsberg TC, Riggs BL: Estrogen stimulates gene expression and protein production of osteoprotegerin in human osteoblastic cells. Endocrinology 1999, 140:4367-4370.

44. Ramalho AC, Jullienne A, Couttet P, Graulet AM, Morieux C, de Vernejoul MC, Cohen-Solal ME: Effect of oestradiol on cytokine production in immortalized human marrow stromal cell lines. Cytokine 2001, 16:126-130.

45. Cutolo M, Wilder RL: Different roles for androgens and estrogens in the susceptibility to autoimmune rheumatic diseases. Rheum Dis Clin North Am 2000, 26:825-839.

46. Kanik KS, Wilder RL: Hormonal alterations in rheumatoid arthritis, including the effects of pregnancy. Rheum Dis Clin North Am 2000, 26:805-823.

\section{Correspondence}

Helena Forsblad d'Elia, Department of Rheumatology and Inflammation Research, The Sahlgrenska Academy at Göteborg University, Guldhedsgatan 10, S-413 46 Göteborg, Sweden. Tel: +46 3134247 69; fax: +463182 39 25; e-mail: helena.forsblad@rheuma.gu.se 